Section Editor

John J. Millichap, MD

Alyx B. Porter, MD
Mystery Case:

\section{Widespread plexiform neurofibromas in neurofibromatosis type 1}

An uncommon cause of back pain
Correspondence to Dr. Porter:

Porter.alyx@mayo.edu

Figure

T2 coronal MRI reveals widespread plexiform neurofibromas emanating from all nerve roots

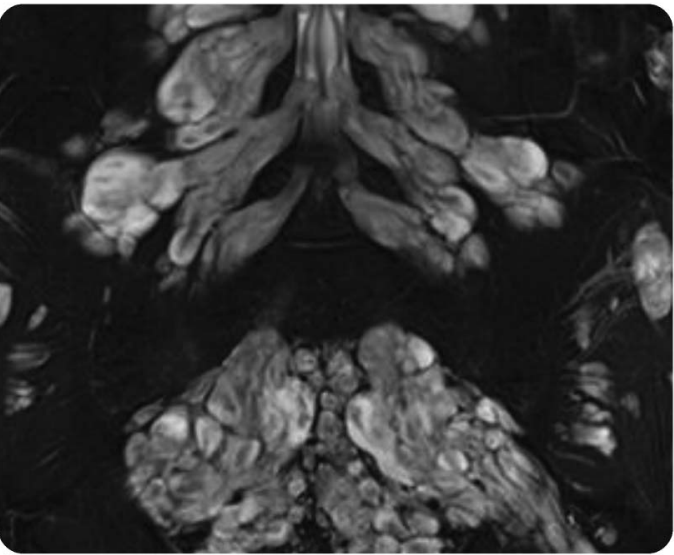

There are very large neurofibromas arising from all of the lumbar and sacral roots consistent with the clinical history of neurofibromatosis type 1. Extensive plexiform neurofibromas involving the pelvis, sciatic nerves, and femoral nerves are seen.

A 23-year-old man with known neurofibromatosis type 1 (NF1) presented with low back pain described as a "wringing" sensation, with radiation to both legs and painful spasms upon awakening. Examination was significant for reduced reflexes bilaterally. The figure is a coronal T2-weighted MRI revealing extensive plexiform neurofibromas arising from all lumbosacral nerve roots. Neurofibromas appear as high signal intensity on T2-weighted images due to increased fluid in myelin associated with dysplastic glial proliferation. ${ }^{1}$ In patients with NF1 presenting with back pain or polyradiculopathy, imaging should be obtained to evaluate for neurofibroma-mediated spinal cord pathology.

\section{AUTHOR CONTRIBUTIONS}

Dr. Grimsrud: drafting/revising the manuscript, study concept or design, analysis or interpretation of data, accepts responsibility for conduct of research and final approval. Dr. Porter: drafting/revising the manuscript, accepts responsibility for conduct of research and final approval, study supervision.

\section{STUDY FUNDING}

No targeted funding reported.

\section{DISCLOSURE}

The authors report no disclosures relevant to the manuscript. Go to Neurology.org for full disclosures.

\section{REFERENCE}

1. Gutmann DH, Parada LF, Silva AJ. Neurofibromatosis type 1: modeling CNS dysfunction. J Neurosci 2012;32:1408714093.

\section{MYSTERY CASE RESPONSES}

The Mystery Case series was initiated by the Neurology ${ }^{\circledR}$ Resident \& Fellow Section to develop the clinical reasoning skills of trainees. Residency programs, medical student preceptors, and individuals were invited to use this Mystery Case as an educational tool. Responses to multiple choice questions formulated using this case were solicited through a group e-mail sent to the American Academy of Neurology Consortium of Neurology Residents and Fellows and through social media. We received 222 responses. The majority of respondents (72\%) had been in practice for $1-4$ years; $57 \%$ were residents or fellows while $32 \%$ were faculty/board-certified physicians. Fifty-seven percent resided outside the United States. A wide range of practice settings was represented.

When presented with information about this young man's presentation with low back pain radiating to both legs with painful spasms, and reduced reflexes bilaterally in the legs, $78 \%$ of respondents

From the Department of Neurology, Mayo Clinic, Scottsdale, AZ. 
appropriately selected MRI of the lumbosacral spine as the investigation of choice. The next 2 frequent choices were MRI thoracic spine (4.5\%) and lumbar puncture $(4.5 \%)$; while these may be helpful in the investigation of certain cases of back pain, lumbosacral spine imaging would be the most helpful first step in this case. We did not disclose the patient's known diagnosis of NF1 in the Mystery Case Quiz, but instead mentioned that on exposure to test L1 sensation, several small hyperpigmented spots were seen in the inguinal region.

Upon then being presented the striking neuroimage for this case (coronal T2-weighted section of the lumbosacral spine) and asked about the most likely diagnosis, $44 \%$ of respondents correctly picked "multiple plexiform neurofibromas with neurofibromatosis type 1." The next most common choices were "multiple lumbosacral schwannomas with neurofibromatosis type 1" (21\%) and "multiple plexiform neurofibromas with neurofibromatosis type 2 " (11\%). Plexiform neurofibromas as seen in this case are hyperintense on T2 due to increased fluid in the myelin associated with dysplastic glial proliferation, whereas schwannomas are typically heterogeneously hyperintense, often with cystic and fatty degeneration. ${ }^{1}$ The parent nerve is classically eccentric to the mass (but within the epineurium) in schwannoma but central or obliterated by the mass in neurofibroma. ${ }^{1}$ Correctly distinguishing between neurofibromas and schwannomas may require histologic examination, but the distinction is crucial as there are both diagnostic and management implications: neurofibromas are generally indicative of NF1 and schwannomas of NF2 or schwannomatosis; schwannomas only rarely undergo malignant change whereas there is a $10 \%$ lifetime risk that plexiform neurofibromas will become malignant peripheral nerve sheath tumors. ${ }^{2}$ Indeed, spinal schwannomas can occur in around $90 \%$ of patients with NF2 and may be among the first signs of NF2 in some young people. ${ }^{3}$

In this Mystery Case quiz, the patient met 2 major disease features of NF1, sufficient to make a clinical diagnosis of NF1: namely, plexiform neurofibromas (numerous, but only one needed) and groin freckling. Seventy-eight respondents (35\%) picked the correct answer for both questions for this case $-56 \%$ were residents, fellows, or medical students.

Aravind Ganesh, MD

Department of Clinical Neurosciences, University of Calgary, Canada; Nuffield Department of Clinical Neurosciences, University of Oxford, UK

\section{REFERENCES}

1. Beaman FD, Kransdorf MJ, Menke DM. Schwannoma: radiologic-pathologic correlation. Radiographics 2004;24: 1477-1481.

2. Ferner RE. The neurofibromatosis. Pract Neurol 2010;10: 82-93.

3. Evans DG, Baser ME, O'Reilly B, et al. Management of the patient and family with neurofibromatosis 2: a consensus conference statement. Br J Neurosurg 2005;19:5-12. 


\title{
Neurology
}

\author{
Mystery Case: Widespread plexiform neurofibromas in neurofibromatosis type 1: An \\ uncommon cause of back pain \\ Kate W. Grimsrud and Alyx B. Porter \\ Neurology 2017;89;e218-e219 \\ DOI 10.1212/WNL.0000000000004595
}

This information is current as of October 30, 2017

\section{Updated Information \&} Services

\section{References}

Subspecialty Collections

\section{Permissions \& Licensing}

Reprints including high resolution figures, can be found at: http://n.neurology.org/content/89/18/e218.full

This article cites 4 articles, 2 of which you can access for free at: http://n.neurology.org/content/89/18/e218.full\#ref-list-1

This article, along with others on similar topics, appears in the following collection(s):

MRI

http://n.neurology.org/cgi/collection/mri

Nerve tumor

http://n.neurology.org/cgi/collection/nerve_tumor

Neurofibromatosis

http://n.neurology.org/cgi/collection/neurofibromatosis

Neuropathic pain

http://n.neurology.org/cgi/collection/neuropathic_pain

Peripheral neuropathy

http://n.neurology.org/cgi/collection/peripheral_neuropathy

Information about reproducing this article in parts (figures,tables) or in its entirety can be found online at:

http://www.neurology.org/about/about_the_journal\#permissions

Information about ordering reprints can be found online:

http://n.neurology.org/subscribers/advertise

Neurology ${ }^{\circledR}$ is the official journal of the American Academy of Neurology. Published continuously since 1951, it is now a weekly with 48 issues per year. Copyright (O 2017 American Academy of Neurology. All rights reserved. Print ISSN: 0028-3878. Online ISSN: 1526-632X.

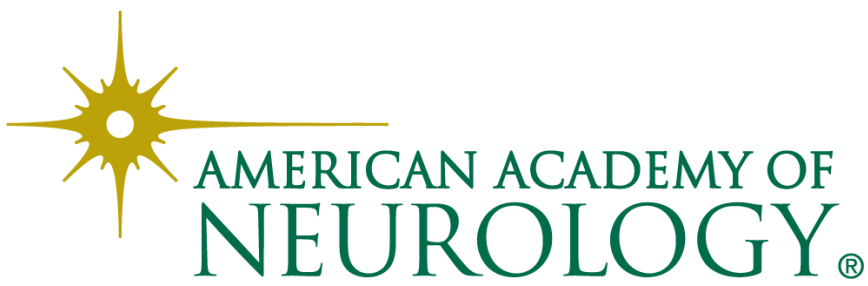

